\title{
Building form and energy efficiency in tropical climates: A case study of Penang, Malaysia
}

\author{
Formato da construção e eficiência energética em climas tropicais: Um estudo \\ de caso de Penang, Malásia
}

Maryam Mohsenzadeh[a] [D, Massoomeh Hedayati Marzbali [b] [D]

Mohammad Javad Maghsoodi Tilaki [c] [D] Aldrin Abdullah[b] (iD)

[a] School of Engineering, Islamic Azad University of Ayatollah Amoli, Amol, Iran

[b] School of Housing, Building and Planning, Universiti Sains Malaysia, 11800 Penang, Malaysia

[c] School of Humanities, Universiti Sains Malaysia, 11800 Penang, Malaysia

How to cite: Mohsenzadeh. M., Marzbali, M. H., Tilaki , M. J. M. \& Abdullah, A. (2021). Building form and energy efficiency in tropical climates: A case study of Penang, Malaysia. urbe. Revista Brasileira de Gestão Urbana, v.13, e20200280. DOI 10.1590/2175-3369.013.e20200280

\begin{abstract}
Malaysia is a nation that has undergone a massive development based on its abundance of fuel supply. The imbalance ratio between gross domestic products and energy demand clearly indicates the need to promote energy-efficiency strategies in the country. This study investigates the relationship between building shape and energy consumption by considering the control of excessive solar radiation in a tropical climate. In the first step, four basic plan geometries, namely, square, rectangle, triangle and circle shapes, are studied to determine the optimal building shape in terms of energy consumption in Penang, Malaysia. Results of simulation analysis using DesignBuilder software (Version 5.4.0) reveal that the circle is the most suitable form in terms of energy performance. In the second step, all buildings with extended shapes based on the optimal shape obtained from the first step are simulated under the same condition to analyse the thermal behaviour of different building forms. Amongst four alternative extended cases, Case 3 with $90 \mathrm{~cm}$ depth and without vertical offset from the top of the window has superior energy performance and sufficient natural daylight. This study contributes to enhance energy efficiency of new buildings by incorporating design strategies in the design process.
\end{abstract}

Keywords: Passive design. Building form. Shading. Energy simulation. Daylighting.

MM, Masters of Architecture, e-mail: maryam.mohsenzade90@gmail.com

MHM, Senior Lecturer in Landscape Architecture, e-mail: hedayati@usm.my; mass.usm@gmail.com (corresponding author) MJMT, Senior Lecturer in Urban Planning, e-mail: maghsoodi@usm.my

AA, Prof. Dr. in Landscape Architecture, e-mail: aldrin@usm.my 


\section{Resumo}

A Malásia é uma nação que passou por um enorme desenvolvimento devido à sua abundância de combustível. A relação desequilibrada entre o Produto Interno Bruto e a demanda de energia indica claramente a necessidade de promover estratégias de eficiência energética no país. Este estudo investiga a relação entre o formato da construção e o consumo de energia, levando em conta o controle da excessiva radiação solar em um clima tropical. Na primeira etapa, quatro formas geométricas planas básicas, quadrado, retângulo, triângulo e círculo, são estudadas para determinar o formato ideal da construção em termos de consumo de energia em Penang, Malásia. Os resultados das análises das simulações usando o software DesignBuilder (versão 5.4.0) revelam que o círculo é a forma mais apropriada em termos de performance de energia. Na segunda etapa, todas as construções com formas ampliadas, baseadas na forma ideal obtida na primeira etapa, são simuladas sob as mesmas condições para analisar o comportamento térmico dos diferentes formatos de construção. Entre quatro casos alternativos ampliados, o Caso 3, com $90 \mathrm{~cm}$ de profundidade e sem deslocamento vertical a partir do topo da janela, tem uma performance energética superior e iluminação natural suficiente. Este estudo contribui para aumentar a eficiência energética de novas construções a partir da incorporação de estratégias de design no processo de design.

Palavras chave: Design passivo. Formato da construção. Sombreamento. Simulação de energia. Iluminação natural.

\section{Introduction}

\section{Building energy use}

The United Nations projects that $68 \%$ of the world population would be living in urban areas by 2050 (United Nations, 2018), resulting in increased urbanisation, climate change and environmental problems (Susca, 2019). The building sector consumes a considerable amount of energy and has become the third largest consumer of natural resources after the industrial and agricultural sectors (Chel \& Kaushik, 2018). Evidence shows that the building sector consumes around 31\% of the total global final energy use and $54 \%$ of the final electricity demand (Carnieletto et al., 2019). The former is expected to increase from $31 \%$ to $95 \%$ between 2005 and 2050 (Levesque et al., 2018).

Population growth is one of the main causes of the increasing demand for fossil fuels in the building sector all over the world. Population growth has critical consequences, such as air pollution and global warming. During the past five decades, the Earth's temperature has risen dramatically. Hence, the use of air conditioning in the building sector and the cooling energy consumption have greatly increased. The huge amount of energy demand can be controlled in several ways, such as promoting behavioural change (Hafner et al., 2019), actively building envelope systems (Luo et al., 2019), assessing the urban environment (Mauree et al., 2019) and evaluating materials (albedo) (Falasca et al., 2019). In particular, utilising novel methods will decrease the global energy demand from buildings by up to $47 \%$ in 2050 and $61 \%$ in 2100 (Levesque et al., 2019).

Researchers have recently focused on reducing global energy consumption (Ballarini et al., 2019). Energy demand in buildings changes considerably across countries and climatic zones (D'Amico et al., 2019). The Association of Southeast Asian Nations (ASEAN) is a region characterised by rapid urbanisation and economic growth. Although the region's climatic conditions are favourable for renewable energy, such as wind and solar, the dominant energy supply comes from nonrenewable resources (Khuong et al., 2019). According to the International Renewable Energy Agency (IRENA, 2018), ASEAN countries differ from others in terms of their national policy frameworks and progress towards the implementation of renewable energy. For instance, the investment trend in solar photovoltaics has dramatically increased in Thailand, Singapore and Indonesia whilst obviously decreasing in Malaysia, Philippines and Vietnam (IRENA, 2018).

Malaysia is a nation that has been widely developed. The building sector in Malaysia is one of the largest and fastest in Southeast Asia. High-rise buildings are sprouting in major cities, such as Kuala Lumpur, Penang and Johor Bahru. The country has undergone a massive development on the basis of its abundance of fuel supply (Energy Malaysia, 2017), and this condition has increased the energy demand for cooling, heating and 
lighting. Due to the imbalance ratio between Gross Domestic Products (GDP) and energy demand, the Malaysian government has implemented incentives to grow the use of energy-efficiency strategies and renewable energies (NEEAP, 2015). Hence, a reasonable point of discussion is the extent to which such massive development can be sustained given the inconsistency in the future fuel market.

Malaysia has hot and humid (tropical) climate throughout the year. This typical subtropical climate is one of the main causes of the increasing electricity consumption in Malaysia as it heightens the need for thermal comfort; meanwhile, fossil fuels are one of the main sources used to generate electricity (Ludin et al., 2019), nearly $90 \%$ of which is produced from fossil fuels, especially natural gas and coal (Muhammad-Sukki et al., 2012). Evidence suggests that buildings, especially in residential and commercial sectors, consume approximately $14.3 \%$ of the overall energy and $53 \%$ of the only electrical energy in Malaysia (Shaikh et al., 2017). This amount of energy consumption is steeply increasing. Occupants use air-conditioning units for thermal comfort, especially during the hot months (Mirrahimi et al., 2016). As a result of the steadily increasing energy demand in the building sector, the Malaysian government has placed energy efficiency as one of the important elements of its energy policy framework through National Energy Efficiency Action Plan (NEEAP, 2015) and Sustainable Energy Development Authority (SEDA, 2019) among others. Hence, promoting efficient utilisation of energy and eliminate wasteful and non-productive patterns of energy are the main focus of the government to achieve sustainable buildings. Therefore, the main goal of this research is to examine the energy savings of buildings after optimisation of building forms through the simulation analysis in the study area.

The United Nations projects that $68 \%$ of the world population would be living in urban areas by 2050 (United Nations, 2018), resulting in increased urbanisation, climate change and environmental problems (Susca, 2019). The building sector consumes a considerable amount of energy and has become the third largest consumer of natural resources after the industrial and agricultural sectors (Chel \& Kaushik, 2018). Evidence shows that the building sector consumes around 31\% of the total global final energy use and $54 \%$ of the final electricity demand (Carnieletto et al., 2019). The former is expected to increase from $31 \%$ to $95 \%$ between 2005 and 2050 (Levesque et al., 2018).

Population growth is one of the main causes of the increasing demand for fossil fuels in the building sector all over the world. Population growth has critical consequences, such as air pollution and global warming. During the past five decades, the Earth's temperature has risen dramatically. Hence, the use of air conditioning in the building sector and the cooling energy consumption have greatly increased. The huge amount of energy demand can be controlled in several ways, such as promoting behavioural change (Hafner et al., 2019), actively building envelope systems (Luo et al., 2019), assessing the urban environment (Mauree et al., 2019) and evaluating materials (albedo) (Falasca et al., 2019). In particular, utilising novel methods will decrease the global energy demand from buildings by up to $47 \%$ in 2050 and 61\% in 2100 (Levesque et al., 2019).

Researchers have recently focused on reducing global energy consumption (Ballarini et al., 2019). Energy demand in buildings changes considerably across countries and climatic zones (D'Amico et al., 2019). The Association of Southeast Asian Nations (ASEAN) is a region characterised by rapid urbanisation and economic growth. Although the region's climatic conditions are favourable for renewable energy, such as wind and solar, the dominant energy supply comes from nonrenewable resources (Khuong et al., 2019). According to the International Renewable Energy Agency (IRENA, 2018), ASEAN countries differ from others in terms of their national policy frameworks and progress towards the implementation of renewable energy. For instance, the investment trend in solar photovoltaics has dramatically increased in Thailand, Singapore and Indonesia whilst obviously decreasing in Malaysia, Philippines and Vietnam (IRENA, 2018).

Malaysia is a nation that has been widely developed. The building sector in Malaysia is one of the largest and fastest in Southeast Asia. High-rise buildings are sprouting in major cities, such as Kuala Lumpur, Penang and Johor Bahru. The country has undergone a massive development on the basis of its abundance of fuel supply (Energy Malaysia, 2017), and this condition has increased the energy demand for cooling, heating and lighting. Due to the imbalance ratio between Gross Domestic Products (GDP) and energy demand, the Malaysian government has implemented incentives to grow the use of energy-efficiency strategies and renewable energies (NEEAP, 2015). Hence, a reasonable point of discussion is the extent to which such massive development can be sustained given the inconsistency in the future fuel market. 
Malaysia has hot and humid (tropical) climate throughout the year. This typical subtropical climate is one of the main causes of the increasing electricity consumption in Malaysia as it heightens the need for thermal comfort; meanwhile, fossil fuels are one of the main sources used to generate electricity (Ludin et al., 2019), nearly $90 \%$ of which is produced from fossil fuels, especially natural gas and coal (Muhammad-Sukki et al., 2012). Evidence suggests that buildings, especially in residential and commercial sectors, consume approximately $14.3 \%$ of the overall energy and $53 \%$ of the only electrical energy in Malaysia (Shaikh et al., 2017). This amount of energy consumption is steeply increasing. Occupants use air-conditioning units for thermal comfort, especially during the hot months (Mirrahimi et al., 2016). As a result of the steadily increasing energy demand in the building sector, the Malaysian government has placed energy efficiency as one of the important elements of its energy policy framework through National Energy Efficiency Action Plan (NEEAP, 2015) and Sustainable Energy Development Authority (SEDA, 2019) among others. Hence, promoting efficient utilisation of energy and eliminate wasteful and non-productive patterns of energy are the main focus of the government to achieve sustainable buildings. Therefore, the main goal of this research is to examine the energy savings of buildings after optimisation of building forms through the simulation analysis in the study area.

\section{Passive design as a mitigation strategy}

Measures are being taken to meet the demand for energy in a large population. However, some of these measures do not include the construction of energy-efficient buildings. As a result, energy consumption increases and thus leads to environmental problems. Although previous attempts to reduce the energy demand have not always been successful (Sorrell, 2015), extensive effort has been exerted to reduce cooling and heating demands in different scales. In the context of the ongoing shortage of natural resources and continued environmental degradation, building energy performance has emerged as an important consideration all over the world.

One of the most sustainable energy techniques is to conserve natural energy resources as much as possible. Research has indicated that the energy performance of buildings depends on five factors, namely, climate, urban geometry, building design, system efficiency and occupant behaviour (Sanaieian et al., 2014). Evidence also suggests that architectural design and form as design strategies reduce energy consumption (Alhuwayil et al., 2019). Under the design and construction zone, passive design strategies and bioclimatic design are amongst the main solutions to decrease energy demand (Mirrahimi et al., 2016). A passive building design, being directly related to energy use, can aid energy conservation efforts (Schiefelbein et al., 2019; Zhang et al., 2019). Studies classified building design factors into five parameters: namely, shape, transparent surface, orientation, thermal-physical properties of building materials and distance between buildings (Pacheco et al., 2012; Rodrigues et al., 2019). In this study, shape refers to virtue of how many sides a building has and its angular relations, while form is described by the area bordered by the lines of a building created. Orientation, aspect ratio, and stacking or vertical proportion also play significant roles among form aspects.

Numerous published studies discuss the interrelationship between climate, especially solar radiation, and energy consumption. Most of these studies can be categorised into four main themes: urban organisation, building form, shading devices and vegetation. Building form has always been an area of interest because of its pivotal role in controlling energy consumption in buildings. Studies found that shape optimisation can reduce building energy demand by approximately 36\% (Aksoy \& Inalli, 2006; A. P. Chan \& Adabre, 2019). In Malaysia, solar radiation received directly or indirectly by buildings causes a rise in the amount of cooling energy consumption (Qahtan, 2019). Solar gain affects building cooling loads, which cover around $50 \%$ of the global cooling loads for buildings (Laine et al., 2019). An appropriate building form allows a building to shade itself to control solar heating. Such case is especially true for 
buildings exposed to excessive direct solar radiation. Evidence suggests that large energy savings in annual cooling loads, ranging from $0.6 \%$ to $10.9 \%$, can be achieved via self-shading (Chan \& Chow, 2014).

\section{Aim of the study}

Although the interest towards passive design strategies has grown in recent years, further research needs to be carried out in various contexts. In Web of Science, a large number of scientific articles match the following keywords: 'urban organisation', 'building form', 'shading devices' and 'vegetation'. However, as the focus of the current study is on building form, the keyword 'energy and building form' was used to search for relevant published articles. A total of 158 related scientific articles were published between 2010 and September 2019. Figure 1 shows the trends in the number of scientific articles published within the said period. A gradual rise is noted in the number of published articles presenting information about the relationship between energy consumption and building form.

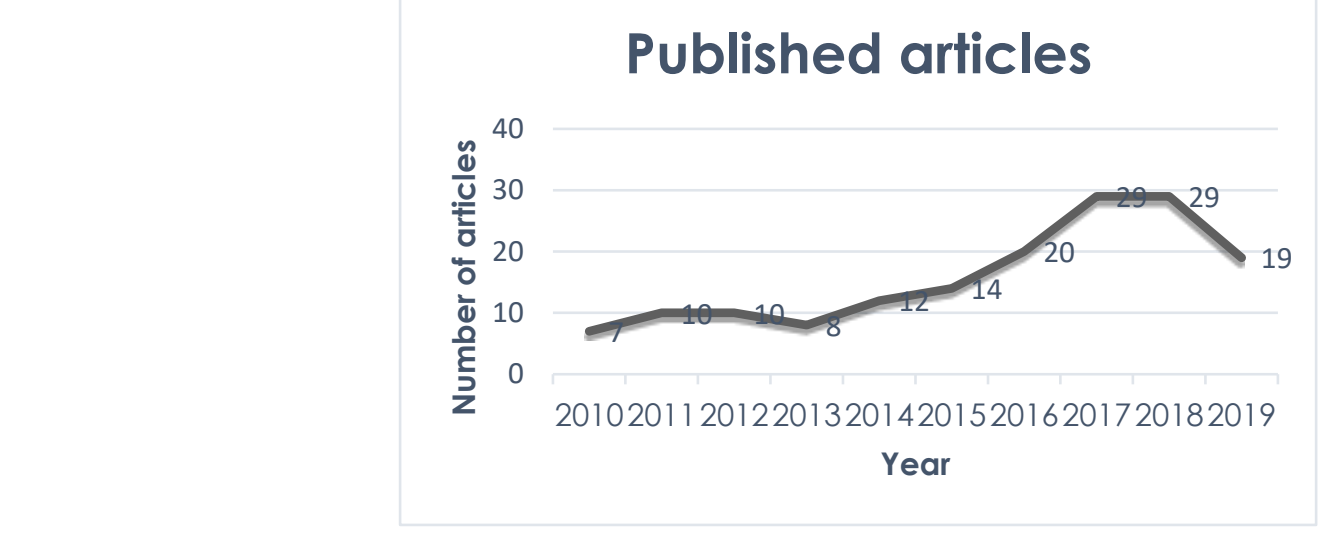

Figure 1 - Number of scientific articles regarding building form and energy published between 2010 and 2019 in Web of Science

In 2010, a limited number of studies investigated building form, and the research topic has transitioned into the investigation on urban planning and a number of specific forms, i.e. courtyard and square, although much uncertainty still exists about the optimal shape and form (Toparlar et al., 2017). The relationship between building basic form and energy demand needs to be studied, along with the impact of extended forms on building shading and energy consumption.

Research has indicated that in addition to a building form's role in creating space, several main aspects include aesthetics (scale, proportion and shape) and the relation between form and function (Dascher, 2019). At present, most studies related to the effects of form factors on building energy consumption can be classified into four categories: (i) heating and cooling load for reducing energy consumption (Biyik \& Kahraman, 2019; Florides et al., 2002; Kannan et al., 2019), (ii) ventilation towards thermal comfort (Patil et al., 2020; St. Clair \& Hyde, 2009), (iii) impact of building shape on energy demand for the study of the cost of life cycle or energy budget (Sharif \& Hammad, 2019; Wang et al., 2006) and (iv) solar access with a focus on daylight purposes and passive heating (Ahn \& Sohn, 2019; Atan \& Ibrahim, 2019; Zhang et al., 2019).

Building cooling load in Malaysia has received critical attention because of the huge amount of solar radiation and the resulting increase in energy consumption. Hence, as a mitigation strategy, external shading could be effective. Designers can apply several strategies to shape buildings in a way that enhances their thermal performance. One of the intelligent strategies to avoid solar radiation in buildings is to provide appropriate shadings. Considering various design strategies is vital in providing appropriate 
shadings, especially for apertures. The concept of self-shaded buildings involves the determination of the building form in a manner that allows self-protection, especially in regions with topical climate (Capeluto, 2003).

Although many works have explored the application of external shading devices, a shading strategy that incorporates the features of self-shading through form extensions has yet to be explored. The current study seeks to investigate the relationship between building shape and energy consumption in high-rise residential buildings in Malaysia. The objective is to understand to what extent building shape and its related components, such as the amount of self-shading, influence building thermal performance. Extended building shapes are considered on the basis of four basic geometric forms (i.e. square, rectangle, circle and triangle), and the optimal shape is determined by considering the control of excessive solar radiation through self-shading during the day.

\section{Materials and methods}

\section{Location and climate type}

The present study focuses on the energy saving potential of incorporating shading with a selfshading envelope through extended forms for high-rise residential buildings under the hot-humid climate of Penang, Malaysia. Malaysia receives a large amount of average daily solar radiation 4500 $\mathrm{kW} / \mathrm{m}^{2}$ and plentiful sunshine around $10 \mathrm{~h}$ per day. The temperature in Malaysia, which is a tropical country located in Southeast Asia, does not fluctuate frequently in the span of a year because of its equatorial climate. Malaysia is located between $1^{\circ}-7^{\circ}$ in the north latitude and $100^{\circ}-120^{\circ}$ in the east longitude, and the average annual rainfall and temperature are $250 \mathrm{~cm}$ and $28^{\circ} \mathrm{C}$, respectively (Hosseini \& Wahid, 2013). The maximum outdoor air temperatures are $31{ }^{\circ} \mathrm{C}-33{ }^{\circ} \mathrm{C}$, and the outdoor relative humidity is constantly above $60 \%$. During the day, wind speed is around $0.91 \mathrm{~m} / \mathrm{s}$ because of the intermonsoon period (Kubota et al., 2018).

Penang, as the study location $\left(5^{\circ} 25^{\prime} \mathrm{N}\right.$, and longitude $\left.100^{\circ} 19^{\prime} \mathrm{E}\right)$, is classified as a place having an 'equatorial hot-humid climate'; the hottest and coolest months are March $\left(24^{\circ} \mathrm{C}-32^{\circ} \mathrm{C}\right)$ and September $\left(23^{\circ} \mathrm{C}-30^{\circ} \mathrm{C}\right)$, respectively, with Georgetown $\left(1785 \mathrm{~kW} / \mathrm{m}^{2}\right)$ receiving one of the highest levels of solar radiation (Soonmin et al., 2019). This amount of solar gain causes a large amount of cooling load; thus, around $42 \%$ of the total electrical energy consumption in Malaysia is allocated to the commercial sector, and $30 \%$ of it is set for residential buildings in response to the cooling energy demand (Sulaiman, 2019).

\section{Study framework}

Although several studies have focused on the relationship between building elements and energy performance, most of them analysed building and system design rather than building geometry (Sanaieian et al., 2014). In generating base design in this work, four basic geometries, i.e. square, rectangle, triangle and circle shapes, are considered as base plans to obtain the optimal building shape in terms of energy consumption in Penang, Malaysia. The modelling and energy simulations are performed using DesignBuilder software. DesignBuilder is simulation software that can consider the envelope and interior elements of buildings.

DesignBuilder software is based on the EnergyPlus engine, which is implemented with a 3D interface and meteorological database. Four geometry plans are studied to simultaneously improve energy performance, thermal comfort and natural daylighting in Penang, Malaysia. After the selection of an optimal basic shape in the first step, four 15-storey buildings with extended forms are simulated using 
DesignBuilder under the same condition to analyse the thermal behaviour and energy consumption of different building forms.

Compactness and shape are some of the most crucial factors that are related to energy requirements. Several studies have assessed the efficacy of aspect ratio in relation to energy consumption and have demonstrated that a direct relationship exists between increasing aspect ratio and energy consumption (Inanici \& Demirbilek, 2000; McKeen \& Fung, 2014). Basically, the ratio between volume and building surface describes the compactness index (V/Aext), and the ratio of building length to building depth expresses the shape factor (Bostancioğlu, 2010; Pathirana et al., 2019).

\section{Modelling and simulation}

The optimisation process comprised two steps. Figure 2 depicts the workflow diagram and sequential steps of optimisation. In the first step, the energy performance of the initial samples consisting of four basic geometric forms was analysed on the basis of three design parameters, namely, dimension, location and orientation. As the focus of this study is building form, the aforementioned design parameters were kept constant during the analysis. For the initial design, all cases were one-storey buildings with a 30\% window-to-wall (WWR) ratio and about $120 \mathrm{~m}^{2}$ floor area. As demonstrated in Table 1, no specific orientation was applied because the forms were compact.

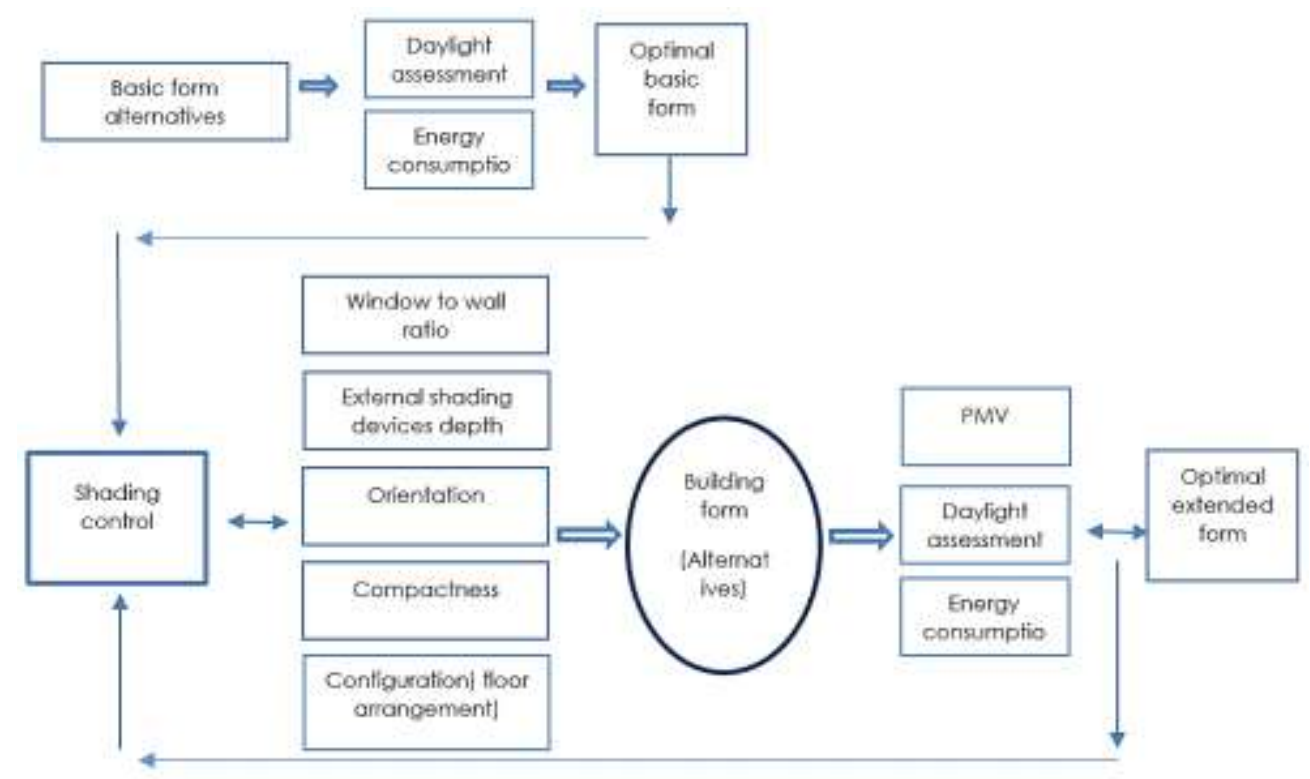

Figure 2 - Workflow diagram and sequential steps of optimization

Table 1 - The basic plan geometries in this study

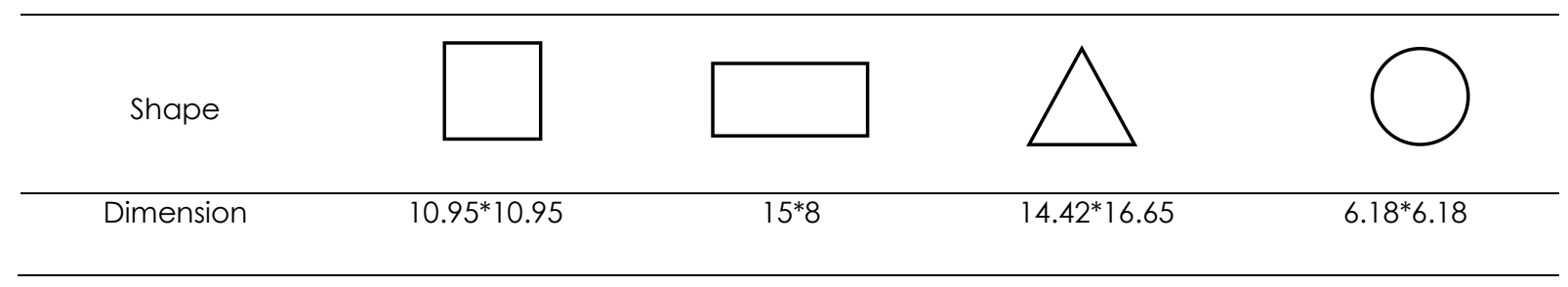

Source: Authors. 
The main parameters of buildings were obtained from DesignBuilder, and test according to ASHRAE Standard 140. The EnergyPlus building energy simulation software has automated the process of testing ASHRAE Standard 140, which is an essential part of EnergyPlus development, with an emphasis on comparative and analytical testing (EnergyPlus, 2019; Neymark et al., 2017). Table 2 shows the simulation input for buildings' properties and operation details.

Table 2 - Simulation inputs for building's properties and operation details.

\begin{tabular}{ll}
\hline Parameter & Specification \\
\hline Building Properties & \\
\hline External wall insulation & XPS (U-Value: 0.350 W/m2-K) \\
\hline Roof insulation & U-Valve: 0.250 W/m2-K \\
\hline Window U-Value & $1.960 \mathrm{~W} / \mathrm{m} 2-\mathrm{K}$ \\
\hline Glazing type & Generic PYR B CLEAR 3mm \\
\hline SHGC & 0.691 \\
\hline Normalized power density & $2.50 \mathrm{~W} / \mathrm{m} 2-100$ lux \\
\hline Window-to-wall ratio (WWR) & $30 \%$ \\
\hline Shading & Without inside shading \\
\hline Building Operation Details & \\
\hline HVAC system type & Fan-Coil Unit (4-Pipe), Air cooled \\
\hline Heating system seasonal & 0.850 \\
CoP & $21^{\circ} \mathrm{C}$ \\
\hline $\begin{array}{l}\text { Heating set point } \\
\text { temperature }\end{array}$ & Natural Gas \\
\hline fuel & 1.800 \\
\hline Cooling & $25^{\circ} \mathrm{C}$ \\
\hline $\begin{array}{l}\text { Cooling set-point } \\
\text { temperature }\end{array}$ & Electricity from grid \\
\hline fuel & 10 L/s-person \\
\hline Fresh air supply rate & 150 lux \\
\hline Lighting target illuminance & LED \\
\hline Type of lighting & 0.0188 people/m2 \\
\hline Occupancy density & \\
\hline
\end{tabular}

Source: Authors.

In the second step, after determining the optimal form in the initial analysis, various alternatives of building forms with self-shading were considered. The high-rise building models had 15-storeys with a floor area of $1200 \mathrm{~m}^{2}$ but four different floor plans. Each façade had a WWR of $30 \%$ for all façade elevations. The floor-to-floor height of the buildings was set to $3.5 \mathrm{~m}$. In the optimisation process, the extended building geometry provided adequate shading during critical hours whilst allowing appropriate daylight. Generally, the optimisation of daylighting requires the consideration of an extensive set of architectural design parameters, including building compactness, building orientation, configuration (floor arrangement), depth of external shading devices and WWR. Amongst these factors, building compactness, WWR and building orientation in all cases were assumed as constant, and the configuration (floor arrangement) and depth of external shading devices were investigated. The depth of external shading devices for self-shading buildings was calculated on summer solstice (solar declination, $23.5^{\circ}$ ) to avoid the penetration of direct solar radiation during daytime. According to Capeluto (2003), $h=\frac{d}{\tan \hat{z}}$, where $\hat{z}(5.29-23.5=-18.21)$ represents the angle between the zenith and the sun and $h$ represents the height (i.e. 3.5). Therefore, $d$ is $2.60 \mathrm{~cm}$. 


\section{Results}

\section{Comparison of basic shape simulation results}

The simultaneous optimisation of building shape and solar gain was conducted on four different building models in Penang, Malaysia. In the first step, buildings with four basic shapes were evaluated in terms of heat exchange. Figure 3 demonstrates the proportions of relevant loads (lighting, cooling and domestic hot water) and the amount of received energy in relation to the gross annual energy (GAE) use as total internal gains. Figure 4 shows the total loads and annual solar gain for all basic building shapes.

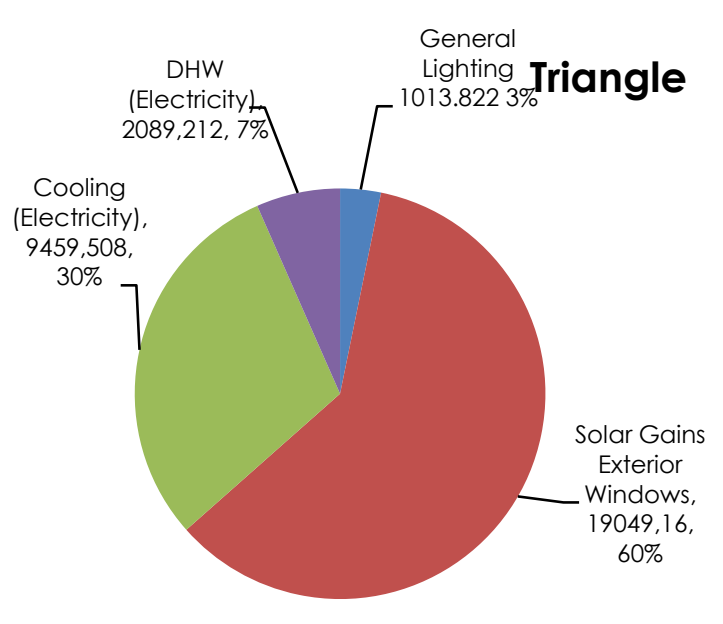

(a)

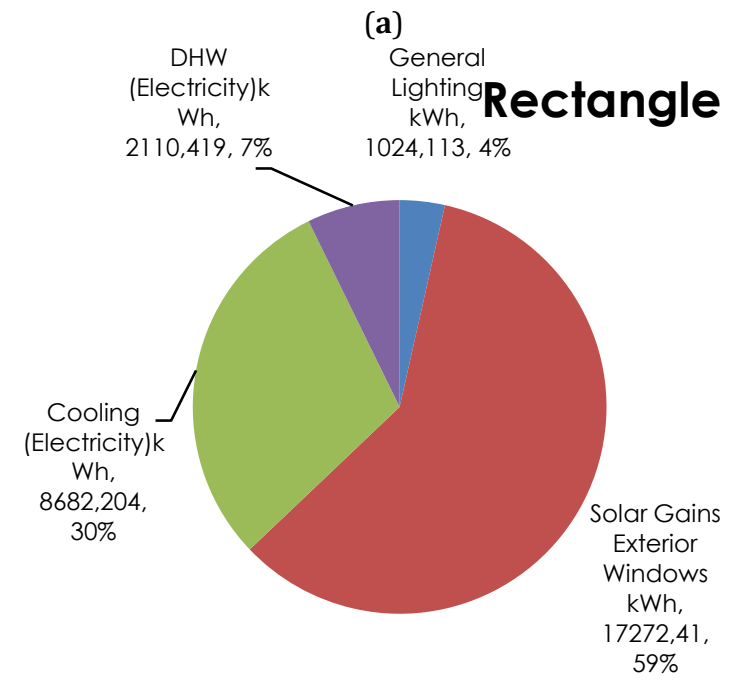

(c)

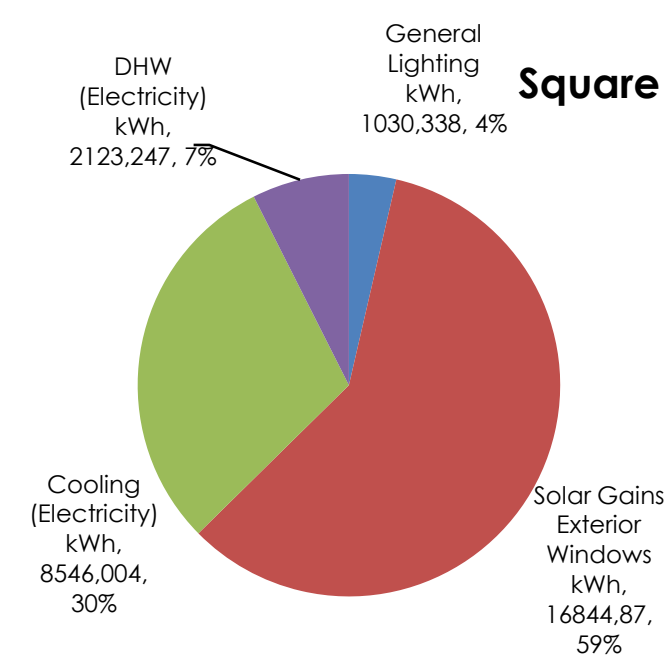

(b)

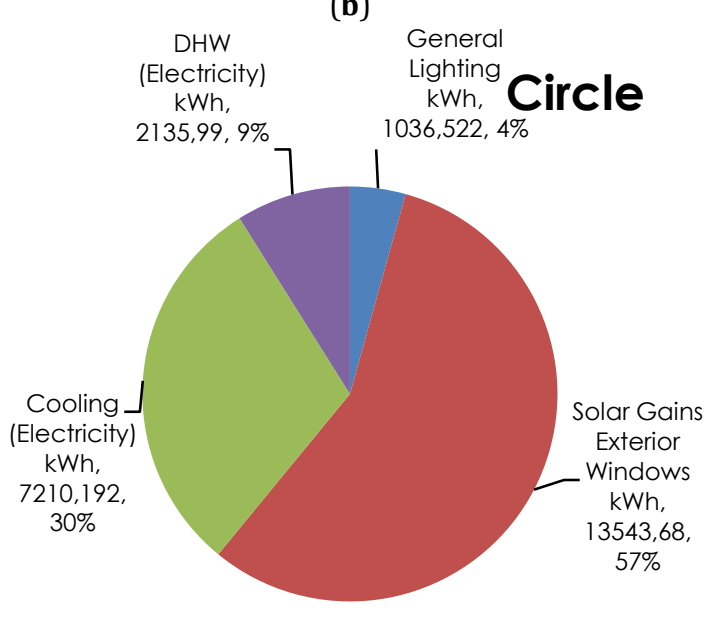

(d)

Figure 3 - The portions of internal gains for four basic shape buildings: (a) A portion of internal gains of the triangle shape; (b) A portion of internal gains of the square shape; (c) A portion of internal gains of the rectangle shape; (d) A portion of internal gains of the circle shape building. 
Figure 3 shows that the largest load was related to solar gain and was greater than $50 \%$ in all cases. The results further indicated that the greatest demand referred to cooling loads because of the large amount of solar gain. No significant differences were found between the demand for domestic hot water and general lighting. As solar radiation is the most critical factor in the overall thermal transfer value equation (Nikpour et al., 2013), intensive solar radiation affects the requirements of employing mechanical cooling mechanisms and considerably increases energy consumption in buildings. Hence, a passive solar building design through building form can aid energy efficiency in buildings (Chel \& Kaushik, 2018).

The results further indicated that the triangle shape received about $60 \%$ of the total heating exchange, followed by the square and rectangle shapes at around $59 \%$ and by the circle shape at approximately $57 \%$ solar radiation. A comparison of the four basic shapes demonstrated that the triangle shape had the highest consumption of about $9459 \mathrm{kWh}$ in a year, whereas the circle shape had undoubtedly the lowest consumption of approximately $7210 \mathrm{kWh}$ annually. The square and rectangle shapes consumed approximately 8546 and $8682 \mathrm{kWh}$. Given the relatively available natural light, the portion of lighting had the lowest energy consumption amongst all alternatives (about 3\%-4\%).

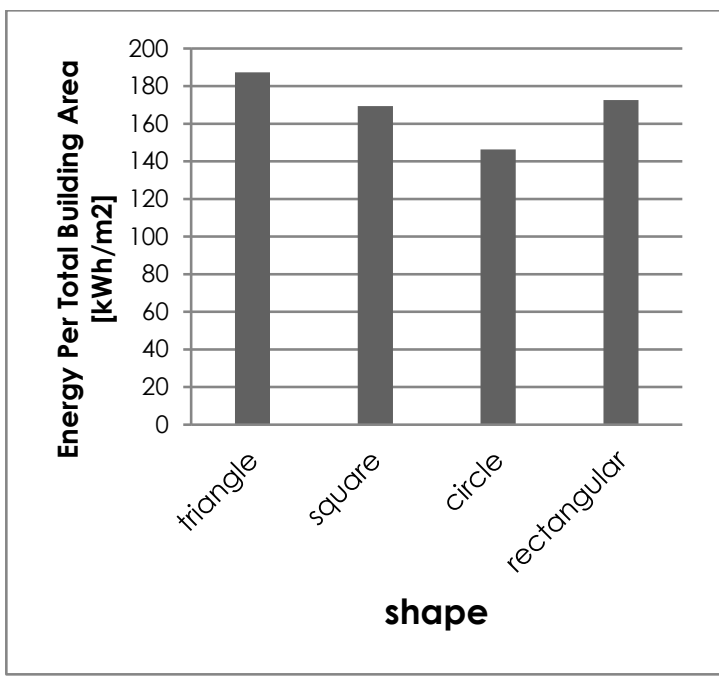

(a)

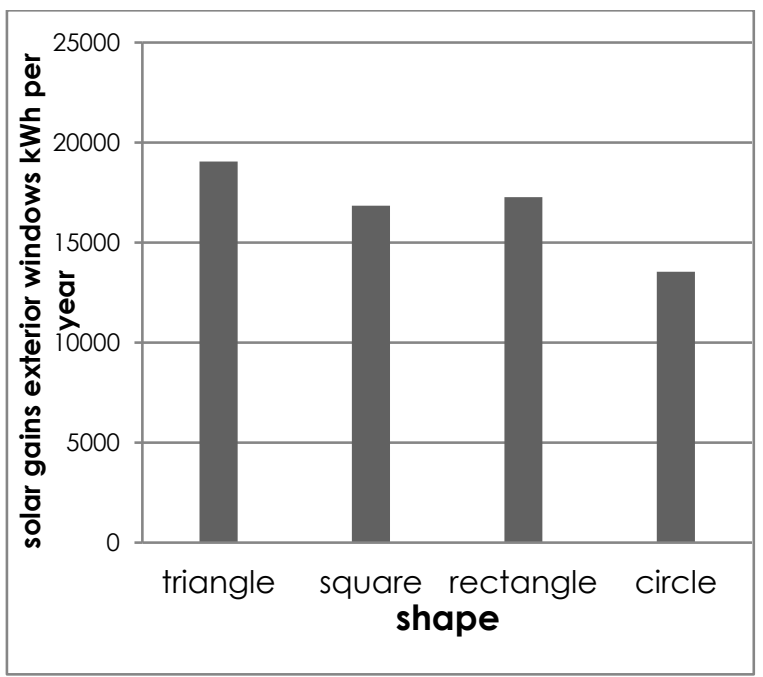

(b)

Figure 4 - Total energy consumption [ $\mathrm{kWh} / \mathrm{m} 2]$ and annual solar gains [ $\mathrm{kWh}$ ] for all basic shapes: (a) Total energy consumption; (b) Annual solar gains.

Consistent with the large body of literature, the results of this study show that the amount of received solar energy depends on building shapes (Alhuwayil et al., 2019). As shown in Figure 4 and given the same area for all shapes, the circle shape achieved the best energy performance at about $146 \mathrm{kWh} / \mathrm{m}^{2}$ (at least $14 \%$ lower than those for the other shapes) because it received the lowest solar gain of $13543 \mathrm{kWh}$ (around 20\% less than those received by the other shapes). Nevertheless, the highest amount of solar gain was related to the triangle shape which influenced cooling load and, consequently, the amount of energy consumption. Moreover, the rectangle shape was the second highest energy consumer and solar gain receiver. The square shape showed the third highest energy consumption.

\section{Comparison of building shape simulation results}

Evidence suggests that several factors and techniques related to building shapes contribute to thermal comfort and energy consumption. In the second step, four 15-storey residential buildings with an average floor area of $1200 \mathrm{~m}^{2}$ were selected to analyse building efficiency, including the effects of 
shape factors on daylight assessment, energy consumption and thermal comfort across all shapes. Table 3 shows four alternative self-shading designs. On the basis of the findings in the first step, these alternative cases were based on the circle shape form as it had the best performance amongst all four shapes in terms of energy efficiency and solar gain.

Table 3 - Descriptions of extended forms

\begin{tabular}{|c|c|c|c|}
\hline Case & Shape & Specification & Reason \\
\hline 1 & & $\begin{array}{l}\text { Self-shading form with three } \\
\text { different areas: } \\
\text { 1. Circular plan with a radius of } \\
22 \mathrm{~m} \text { and area of } 1519 \mathrm{~m}^{2} \\
\text { 2. Circular plan with a radius of } \\
19.5 \mathrm{~m} \text { and area of } 1200 \mathrm{~m}^{2} \\
\text { 3. Circular plan with a radius of } \\
17 \mathrm{~m} \text { and area of } 907 \mathrm{~m}^{2}\end{array}$ & $\begin{array}{l}\text { A self-shading building is amongst the } \\
\text { several types of building design with } \\
\text { exterior facades that could enhance } \\
\text { buildings' thermal performance. It can } \\
\text { control direct solar heat gains through its } \\
\text { upside-down pyramidal shape (Example: } \\
\text { Energy Commission Building [Diamond } \\
\text { Building] in Putrajaya, Malaysia). }\end{array}$ \\
\hline 2 & & $\begin{array}{c}\text { - Circular plan with a radius of } \\
19.5 \mathrm{~m} \text { and area of } 1200 \mathrm{~m}^{2} \\
\text { - Indentation form to a depth of } \\
1 \mathrm{~m} \text { in every } 380 \mathrm{~cm}\end{array}$ & $\begin{array}{c}\text { The vertical shading affords efficient } \\
\text { shading, especially for the east and west } \\
\text { facades. This shading not only acts as a } \\
\text { windbreak but also improves glass } \\
\text { insulation value in the heating period } \\
\text { (Example: Three elegant towers of Troika, } \\
\text { KOMTAR). }\end{array}$ \\
\hline 3 & 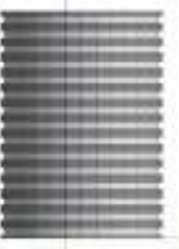 & $\begin{array}{l}\text { - Circular plan with a radius of } \\
19.5 \mathrm{~m} \text { and area of } 1200 \mathrm{~m}^{2} \\
\text { - With } 0.8 \mathrm{~cm} \text { O.K.B, } 150 \mathrm{~cm} \\
\text { window height and } 90 \mathrm{~cm} \text { depth } \\
\text { (overhang) }\end{array}$ & $\begin{array}{l}\text { An overhang is a horizontal surface that } \\
\text { extends over a window to provide shade } \\
\text { (Example: UMNO Tower Penang). }\end{array}$ \\
\hline 4 & & $\begin{array}{l}\text { - Spiral tower, circular plan with } \\
\text { a radius of } 19.5 \mathrm{~m} \text { and area of } \\
1200 \mathrm{~m}^{2} \\
\text { - About a 50-degree orientation } \\
\text { around a central axis per floor }\end{array}$ & $\begin{array}{c}\text { Twisted buildings in modern architecture } \\
\text { come in several types, such as twister } \\
\text { category, Tordo category, sliding twister } \\
\text { category and helical twister category } \\
\text { (Examples: Agora Tower, Taipei, Taiwan } \\
\text { and Mesiniaga, Gensler's Shanghai } \\
\text { Tower, Shanghai, China). }\end{array}$ \\
\hline
\end{tabular}

Source: Authors.

\section{Effects of shape factors on daylight assessment}

Sufficient daylight provides comfortable and satisfying indoor conditions. Sufficient daylight can play a pivotal role in decreasing electrical lighting requirements. However, high luminance causes heat gains and glare problems. In the simulation, potential glare spots were avoided by the estimated shading devices and building form. The models were presented as residential buildings, where light work was not the main activity of the occupants. An average daylight factor of $2 \%$ is recommended as a sufficient daylight factor for Malaysia (Nedhal et al., 2016).

An acceptable range of indoor illuminance for a residential building in Penang is 200-300 lux (Dogan \& Park, 2017; Susan \& Prihatmanti, 2017). As demonstrated in Figure 5, Cases 2, 3 and 4 fell within the standard range of indoor illuminance. Overall, Case 3 provided the highest amount of average daylight factor, and Case 1 had the lowest amount of average daylight factor, which was around $40 \%$ lower than that of Case 3. Meanwhile, no significant difference was noted between Case 2 and Case 4, both of which 
had the second highest amount of daylight factor. In terms of annual average daylight factor, Case 1 provided around 144 lux, followed by Case 4 (199 lux), Case 2 (215 lux) and Case 3 (359 lux). Amongst the four cases, Case 3 showed the greatest difference, which ranged from $50 \%$ to $100 \%$ relative to the other cases. Cases 1 and 4 received a lower average daylight factor than Case 3 because of their lower shading device depth.

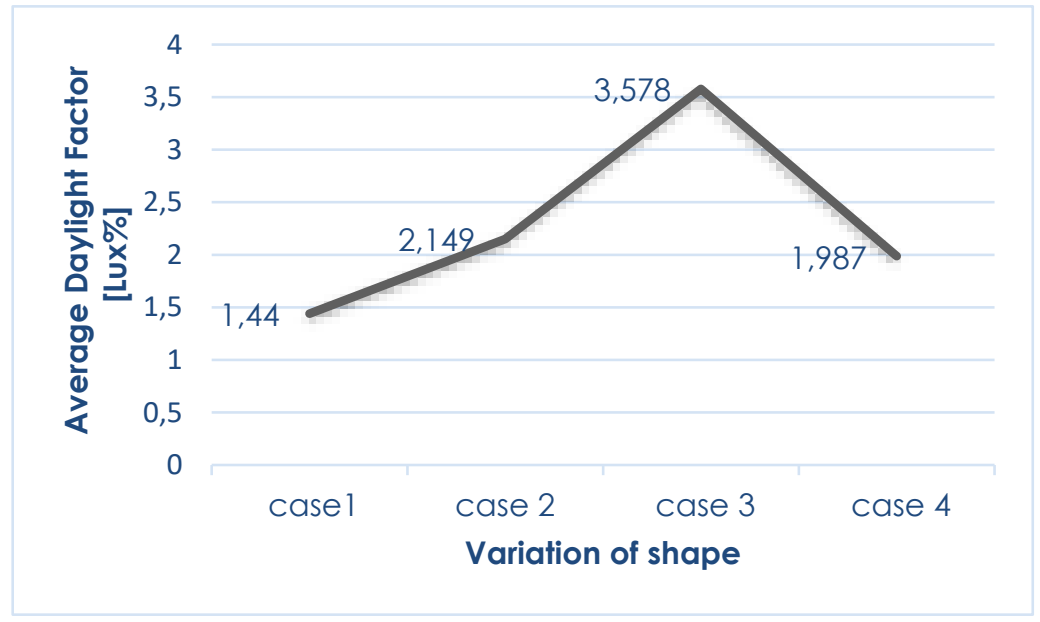

Figure 5 - The annual average daylight factor [lux\%].

\section{Effect of shape factors on energy consumption}

The evaluation of building energy consumption is an essential step in the optimisation of building energy performance. Optimisation means obtaining the best solution(s) amongst different possible alternatives (Kheiri, 2018). Amongst existing strategies, building form plays a key role in optimising building energy performance. In this section, the analysis focuses on the influence of building shape on annual energy consumption and the energy efficiency index (EEI). The EEI refers to the ratio of energy consumption $(\mathrm{kWh})$ per unit floor area $\left(\mathrm{m}^{2}\right)$.

Figure 6 shows a direct relationship between the EEI and the amount of solar gains. An increase in solar gain contributed to an increase in the EEI. The results further demonstrated that Case 1, an upsidedown pyramid, received the lowest amount of solar gain and consumed the lowest energy at 73.78 $\mathrm{kWh} / \mathrm{m}^{2}$ amongst all cases. However, this low amount of solar gain may lead to an insufficient supply of natural light. In terms of net annual energy use, Case 2, an indentation building form, was the least efficient due to the high energy demand and large solar gain. Case 3 with an annual energy consumption of $80.51 \mathrm{kWh} / \mathrm{m}^{2}$ was the second highest energy consumer. Case 4 , the spiral building form, received sufficient solar radiation and consumed a low amount of energy. For residential buildings, 150-400 $\mathrm{kWh} / \mathrm{m}^{2} /$ year is recommended as the acceptable range of the EEI (Abu Bakar et al., 2015). All cases herein were within the acceptable range. A comparison of the solar gains in all cases indicated that building forms can reduce direct solar gain by up to $33 \%$. 

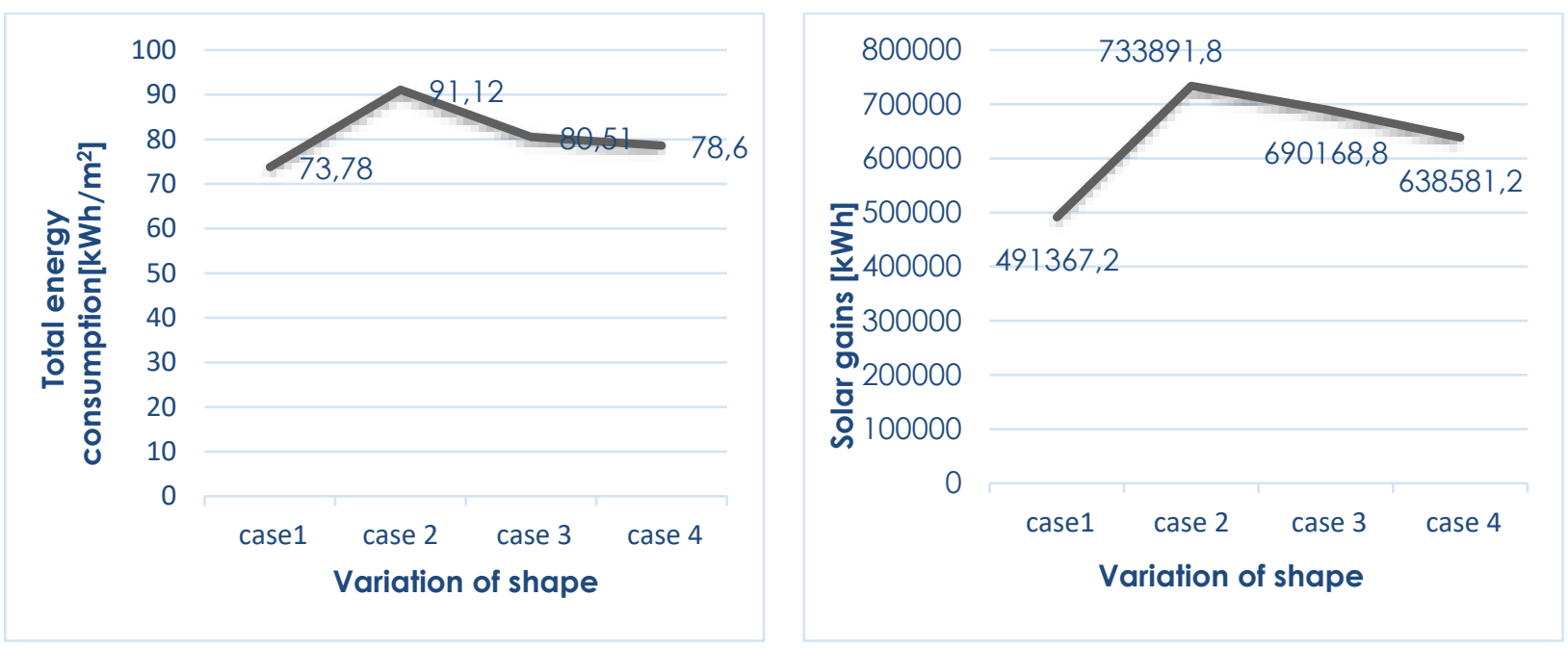

Figure 6 - Energy efficiency index (EEI) [kWh/m²] (left) and annual solar gains [kWh] for all building forms (right)

To assess the impact of building forms on energy performance, we investigated the total cooling loads for all cases. Figure 7 presents cooling loads in a bar chart which shows fluctuations. According to the sun path diagram in Malaysia, the solar radiation increases during February to March and August to October, whereas the low solar radiation occurs from November to January. The same trend was observed in this study. The cooling load was the highest in March at $50000 \mathrm{kWh}$ and the lowest in October. The cooling load gradually decreased from March to October. Amongst all cases, Case 1 showed the lowest total cooling load ( $30346.01 \mathrm{kWh}$ ) in October, followed by Case 4, Case 3 and Case 2 . Case 2 showed the highest amount of cooling load (38222 kWh) amongst all cases. These results indicate that the cooling demand is closely related to solar radiation on the vertical surfaces of buildings.

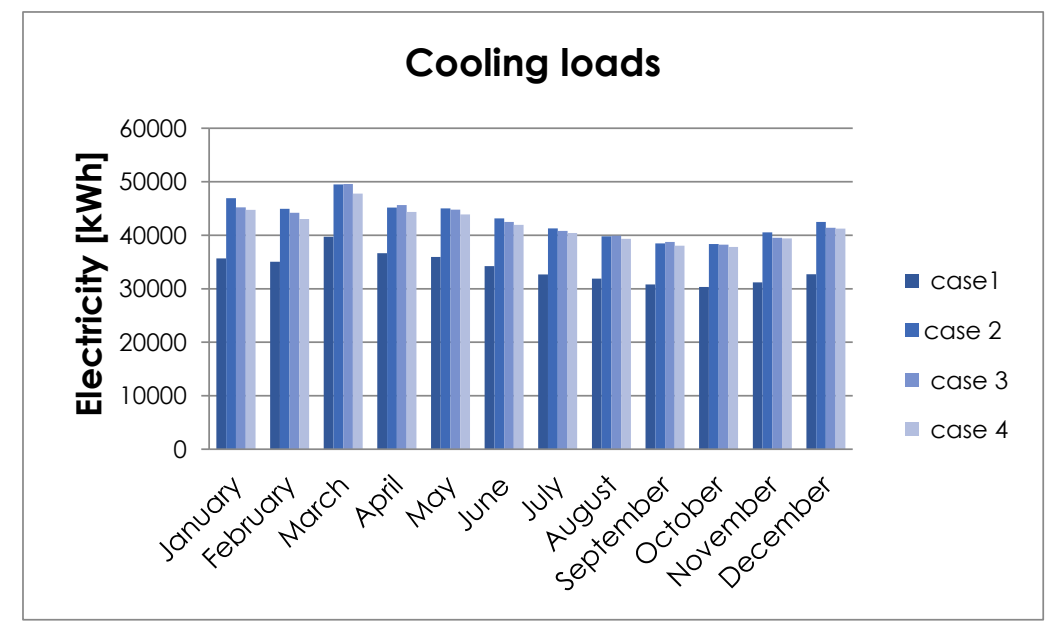

Figure 7 - Total cooling loads for all building forms [kWh]

\section{Effect of shape factors on thermal comfort}

The final section of the analysis investigated the thermal comfort of occupants by examining the predicted mean vote (PMV) index as a notable thermal comfort index. Thermal comfort was measured by Fanger's PMV model on the basis of six factors, namely, air temperature, air velocity, mean radiant 
temperature, relative humidity, clothing and metabolic rate (Ricciu et al., 2018). The first four factors were categorised as environmental factors whilst the last two factors were categorised under personal factors. As noted by Daghigh (2015), the PMV index quantifies the degree of comfort and is shown as a psychophysical scale of hot $(+3)$, warm $(+2)$, slightly warm $(+1)$, neutral $(0)$, slightly cool $(-1)$, cool $(-2)$ and cold $(-3)$. The most suitable range is between -1 and +1 .

Figure 8 shows that the PMV value ranged from +0.3 to +0.5 . The values were positive due to the average temperature of Penang, Malaysia being always higher than $0^{\circ} \mathrm{C}$. At first glance, the PMV values in all cases were within the acceptable range $(-1$ and +1$)$. However, the results showed minor differences which could influence the overall thermal comfort. Thermal balance is maintained when the internal heat gain is equal to heat loss. Case 2 showed the largest PMV index, whereas Case 1 had the minimum PMV index and the greatest thermal comfort. Cases 2 and 4 also showed an average thermal balance. These results indicate that building form plays a vital role in achieving a comfortable indoor environment and, consequently, the total energy demand of buildings.

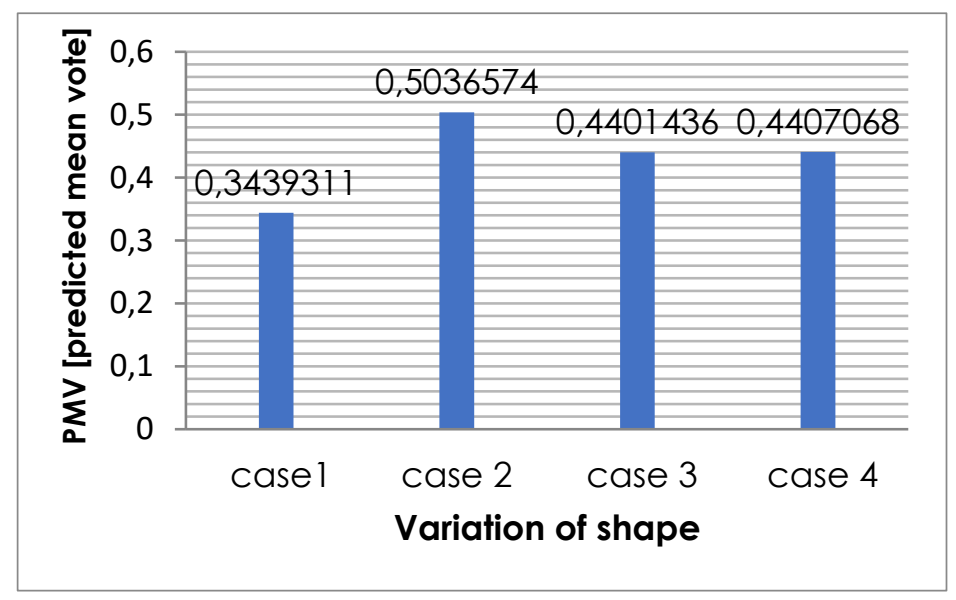

Figure 8 - The PMV index among all cases

\section{Discussions}

In Malaysia, the constant and intensive exposure to solar radiation of building surfaces causes an increase in energy demand for cooling purposes. Therefore, building surfaces need to be protected to reduce the direct or indirect inflow of heat. In the current work, we aim to investigate the impact of building shape on energy consumption by considering passive design to control excessive solar radiation. The study provides a comprehensive approach to optimising the design of building envelopes and increasing thermal comfort, energy performance and natural daylighting. In the first step, four basic building forms, namely, rectangle, square, triangle and circle shapes, were analysed. The results showed that the circle was the most suitable form in terms of energy performance. The second step investigated the extended building forms on the basis of the optimal shape obtained from the first step under Penang's climate. All extended forms were purely geometrical and are common in architecture modelling. Simplicity, popularity and solar potential were amongst the factors considered in developing the alternatives.

In general, all alternatives were within acceptable ranges, but all of them presented advantages and disadvantages. The results indicated that the upside-down pyramid-shaped building (Case 1) with an average radius of $19.5 \mathrm{~m}$ and area of $1200 \mathrm{~m}^{2}$ was the best alternative in terms of energy use (73.78 
$\mathrm{kWh} / \mathrm{m}^{2}$ ) and PMV (0.34). However, in terms of daylight factor, the worst performance measured about 144 lux, which indicated insufficient natural daylight.

By contrast, the indentation building form (Case 2) showed the worst building form in terms of energy consumption and thermal comfort index. Although this form obtained an acceptable daylight factor of approximately 214 lux, it could not be chosen as an optimum alternative. Case 3 with an average radius of $19.5 \mathrm{~m}$ had the greatest daylight factor provision of approximately 358 lux (around $66 \%$ greater than that of the other cases). However, in terms of energy performance, Case 3 ranked third and was amongst the best alternatives in terms of thermal comfort index (0.44) based on Fanger model. Lastly, the spiral form (Case 4) showed good results in terms of energy consumption $\left(78.60 \mathrm{kWh} / \mathrm{m}^{2}\right)$ and natural daylighting (199 lux). In addition, no significant difference was observed between Case 4 and Case 3 with regard to thermal comfort index.

Building shape factors, especially those related to shading, play an important role in reducing building energy consumption. This argument is consistent with the findings of Capeluto (2003), who improved the energy performance for all orientations of a building with a self-shading envelope. In the hot-humid climate of Saudi Arabia, Alhuwayil et al. (2019) found that an advanced shading could reduce the annual energy consumption of a building by approximately $20.5 \%$.

In sum, building forms serve as the optimal solution for the hot-humid region of Penang, Malaysia. Case 1 and Case 3 showed better energy performance than Case 2 and Case 4 because of their particular specifications. Case 1 with a $260 \mathrm{~cm}$ depth and $110 \mathrm{~cm}$ vertical offset from the top of a window and Case 3 with a $90 \mathrm{~cm}$ depth without a vertical offset from the top of a window revealed that the depth of horizontal shading is highly effective in improving energy performance. A comparison of all cases revealed that Case 1 had the lowest total energy consumption of around $73.78 \mathrm{kWh} / \mathrm{m}^{2}$ and that Case 2 had the highest energy consumption of approximately $91.12 \mathrm{kWh} / \mathrm{m}^{2}$. This result shows that the optimisation of building shape can reduce building energy demand by up to $19 \%$ in the study location. Overall, Case 1 and Case 2 could not be considered as the best alternatives of their low daylight factor and high energy consumption, respectively. Case 3 and Case 4 were close in terms of thermal comfort, EEI and energy consumption. However, Case 3 provided more sufficient natural daylight than Case 4 .

Another interesting finding is that a circular building shape with horizontal shading is better than that with vertical shading. Thus, in general, the self-shading approach in buildings, especially in high-rise buildings, contributes to the improvement of building energy performance by providing sufficient natural daylight and a comfortable indoor environment. This study can be considered as an important step in understanding the effects of high-rise building forms on energy performance.

\section{Limitations and implications of the study}

The findings of this study could also be applicable to areas with similar climate conditions. However, these observations are limited, and some other aspects of passive design can be further explored on the basis of this work. One limitation of this work is the constant value of the WWR. Further investigation is necessary to explore the effects of various WWRs and building forms on energy performance and solar gain. The lack of consideration of operation costs, solar photovoltaic potential, other diverse forms and other climate zones are other important limitations of this study that warrant further investigations.

Energy efficiency is amongst the prime objectives of the energy policy in the country. In line with National Energy Efficiency Action Plan (NEEAP, 2015), this study contributes to enhance energy efficiency of new buildings by incorporating design strategies in the design process. Evidence suggests that the design of buildings by designers and architects is mostly focused on the aesthetic values rather than energy performance and climate conditions. Meanwhile, residents as users of residential buildings are not aware of how much energy is being consumed or wasted in their routine activities. Hence, 
professionals must find a novel way to save energy whilst taking into consideration the daily needs of residents. The function of a building form depends on the shape and properties that are influenced by temperature, solar gain, wind and humidity. Therefore, setting out a suitable relationship between buildings and climate is a challenge for architects.

\section{Acknowledgement}

This research was funded by Univeriti Sains Malaysia under Research University Grant (RUI), grant number 1001/PPBGN/8016111.

\section{References}

Abu Bakar, N. N., Hassan, M. Y., Abdullah, H., Rahman, H. A., Abdullah, M. P., Hussin, F., \& Bandi, M. (2015). Energy efficiency index as an indicator for measuring building energy performance: A review. Renewable and Sustainable Energy Reviews, 44,1-11. https://doi.org/10.1016/j.rser.2014.12.018.

Ahn, Y., \& Sohn, D.-W. (2019). The effect of neighbourhood-level urban form on residential building energy use: A GISbased model using building energy benchmarking data in Seattle. Energy and Buildings, 196, 124-133. https://doi.org/10.1016/j.enbuild.2019.05.018.

Aksoy, U. T., \& Inalli, M. (2006). Impacts of some building passive design parameters on heating demand for a cold region. Building and environment, 41(12), 1742-1754. https://doi.org/10.1016/j.buildenv.2005.07.011.

Alhuwayil, W. K., Mujeebu, M. A., \& Algarny, A. M. M. (2019). Impact of external shading strategy on energy performance of multi-story hotel building in hot-humid climate. Energy, 169, 1166-1174. https://doi.org/10.1016/j.energy.2018.12.069.

Atan, A., \& Ibrahim, N. L. N. (2019). Daylight simulation of different light well types in single story terrace houses. Alam Cipta, 12(1), 2-7.

Ballarini, I., De Luca, G., Paragamyan, A., Pellegrino, A., \& Corrado, V. (2019). Transformation of an office building into a nearly zero energy building (nZEB): Implications for thermal and visual comfort and energy performance. Energies, 12(5), 895.

Biyik, E., \& Kahraman, A. (2019). A predictive control strategy for optimal management of peak load, thermal comfort, energy storage and renewables in multi-zone buildings. Journal of Building Engineering, 25, 100826. https://doi.org/10.1016/j.jobe.2019.100826.

Bostancioğlu, E. (2010). Effect of building shape on a residential building's construction, energy and life cycle costs. Architectural Science Review, 53(4), 441-467.

Capeluto, I. G. (2003). Energy performance of the self-shading building envelope. Energy and Buildings, 35(3), 327-336.

Carnieletto, L., Badenes, B., Belliardi, M., Bernardi, A., Graci, S., Emmi, G., Urchueguía, J.F., Zarrella, A., Di Bella, A., Dalla Santa, G., Galgaro, A., Mezzasalma, G., \& De Carli, M. (2019). A European Database of Building Energy Profiles to Support the Design of Ground Source Heat Pumps. Energies, 12(13), 2496.

Chan, A. P., \& Adabre, M. A. (2019). Bridging the gap between sustainable housing and affordable housing: The required critical success criteria (CSC). Building and environment, 151, 112-125. https://doi.org/10.1016/j.buildenv.2019.01.029.

Chan, A., \& Chow, T. (2014). Thermal performance of air-conditioned office buildings constructed with inclined walls in different climates in China. Applied Energy, 114, 45-57.

Chel, A., \& Kaushik, G. (2018). Renewable energy technologies for sustainable development of energy efficient building. Alexandria Engineering Journal, 57(2), 655-669.

Daghigh, R. (2015). Assessing the thermal comfort and ventilation in Malaysia and the surrounding regions. Renewable and Sustainable Energy Reviews, 48, 681-691. https://doi.org/10.1016/j.rser.2015.04.017. 
D'Amico, A., Ciulla, G., Panno, D., \& Ferrari, S. (2019). Building energy demand assessment through heating degree days: The importance of a climatic dataset. Applied Energy, 242, 1285-1306. https://doi.org/10.1016/j.apenergy.2019.03.167.

Dascher, K. (2019). Function follows form. Journal of Housing Economics, 44, 131-140. https://doi.org/10.1016/j.jhe.2018.08.003.

Dogan, T., \& Park, Y. C. (2017). A new framework for residential daylight performance evaluation. Paper presented at the Proceedings of the 15th IBPSA Conference, (p. 170-178). San Francisco, USA.

Energy Malaysia. (2017). Energy in Malaysia: Towards a Brighter Future (Vol. 12). Kuala Lumpur, Malaysia: Energy Commission.

EnergyPlus. (2019). US Department of Energy. Retrieved on January 7, 2019, from www.energyplus.net

Falasca, S., Ciancio, V., Salata, F., Golasi, I., Rosso, F., \& Curci, G. (2019). High albedo materials to counteract heat waves in cities: An assessment of meteorology, buildings energy needs and pedestrian thermal comfort. Building and environment, 163, 106242.

Florides, G. A., Tassou, S. A., Kalogirou, S. A., \& Wrobel, L. (2002). Measures used to lower building energy consumption and their cost effectiveness. Applied Energy, 73(3-4), 299-328.

Hafner, R. J., Elmes, D., \& Read, D. (2019). Promoting behavioural change to reduce thermal energy demand in households: A review. Renewable and Sustainable Energy Reviews, 102, 205-214.

Hosseini, S. E., \& Wahid, M. A. (2013). Feasibility study of biogas production and utilization as a source of renewable energy in Malaysia. Renewable and Sustainable Energy Reviews, 19, 454-462.

Inanici, M. N., \& Demirbilek, F. N. (2000). Thermal performance optimization of building aspect ratio and south window size in five cities having different climatic characteristics of Turkey. Building and environment, 35(1), 41-52.

IRENA. (2018). IRENA. (2018). Renewable Energy Market Analysis: Southeast Asia. Abu Dhabi: International Renewable Energy Agency (IRENA). Retrieved on April 1, 2019, from www.irena.org

Kannan, T., Lork, C., Tushar, W., Yuen, C., Wong, N. C., \& Tai, S. (2019). Energy Management Strategy for Zone Cooling Load Demand Reduction with Occupancy Thermal Comfort Margin. Paper presented at the 2019 IEEE PES GTD Grand International Conference and Exposition Asia (GTD Asia) (p. 247-252), Bangkok, Thailand: IEEE.

Kheiri, F. (2018). A review on optimization methods applied in energy-efficient building geometry and envelope design. Renewable and Sustainable Energy Reviews, 92, 897-920.

Khuong, P. M., McKenna, R., \& Fichtner, W. (2019). Analyzing drivers of renewable energy development in Southeast Asia countries with correlation and decomposition methods. Journal of Cleaner Production, 213, 710-722. https://doi.org/10.1016/j.jclepro.2018.12.192.

Kubota, T., Rijal, H. B., \& Takaguchi, H. (2018). Sustainable Houses and Living in the Hot-Humid Climates of Asia. Singapore: Springer.

Laine, H. S., Salpakari, J., Looney, E. E., Savin, H., Peters, I. M., \& Buonassisi, T. (2019). Meeting global cooling demand with photovoltaics during the 21st century. Energy \& Environmental Science, 12, 2706-2716. https://doi.org/10.1039/c9ee00002j.

Levesque, A., Pietzcker, R. C., \& Luderer, G. (2019). Halving energy demand from buildings: The impact of low consumption practices. Technological Forecasting and Social Change, 146, 253-266. https://doi.org/10.1016/j.techfore.2019.04.025.

Levesque, A., Pietzcker, R. C., Baumstark, L., De Stercke, S., Grübler, A., \& Luderer, G. (2018). How much energy will buildings consume in 2100? A global perspective within a scenario framework. Energy, 148, 514-527. https://doi.org/10.1016/j.energy.2018.01.139.

Ludin, N. A., Junedi, M. M., Affandi, N. A. A., Ibrahim, M. A., Sopian, K., Teridi, M. A. M., Sepeai, S., Su'ait, M. S., \& Haw, L. C. (2019). Energy efficiency action plan for a public hospital in Malaysia. Alam Cipta, 12(Special Issue 1), 73-79.

Luo, Y., Zhang, L., Bozlar, M., Liu, Z., Guo, H., \& Meggers, F. (2019). Active building envelope systems toward renewable and sustainable energy. Renewable and Sustainable Energy Reviews, 104, 470-491. https://doi.org/10.1016/j.rser.2019.01.005. 
Mauree, D., Naboni, E., Coccolo, S., Perera, A., Nik, V. M., \& Scartezzini, J.-L. (2019). A review of assessment methods for the urban environment and its energy sustainability to guarantee climate adaptation of future cities. Renewable and Sustainable Energy Reviews, 112, 733-746. https://doi.org/10.1016/j.rser.2019.06.005.

McKeen, P., \& Fung, A. (2014). The effect of building aspect ratio on energy efficiency: A case study for multi-unit residential buildings in Canada. Buildings, 4(3), 336-354.

Mirrahimi, S., Mohamed, M. F., Haw, L. C., Ibrahim, N. L. N., Yusoff, W. F. M., \& Aflaki, A. (2016). The effect of building envelope on the thermal comfort and energy saving for high-rise buildings in hot-humid climate. Renewable and Sustainable Energy Reviews, 53, 1508-1519. https://doi.org/10.1016/j.rser.2015.09.055.

Muhammad-Sukki, F., Munir, A. B., Ramirez-Iniguez, R., Abu-Bakar, S. H., Yasin, S. H. M., McMeekin, S. G., \& Stewart, B. G. (2012). Solar photovoltaic in Malaysia: the way forward. Renewable and Sustainable Energy Reviews, 16(7), 5232-5244.

Nedhal, A.-T., Syed, F. S. F., \& Adel, A. (2016). Relationship between window-to-floor area ratio and single-point daylight factor in varied residential rooms in Malaysia. Indian Journal of Science and Technology, 9(33), 22-30.

NEEAP. (2015). National Energy Efficiency Action Plan (NEEAP). Putrajaya: Ministry of Energy, Green Technology and Water, Retrieved on March 3, 2019, from https://www.mestecc.gov.my/web/wp-content/uploads/2019/04/13.National-Energy-Efficiency-Action-Plan-english-only.pdf.

Neymark, J., Kennedy, M., Judkoff, R., Gall, J., Henninger, R., Hong, T., \& Zhou, X. (2017). Airside HVAC BESTEST: HVAC AirDistribution System Model Test Cases for ASHRAE Standard 140. Paper presented at the Proceedings of the 15th IBPSA Conference, (p. 644-653). San Francisco, USA.

Nikpour, M., Kandar, M. Z., \& Mosavi, E. (2013). Investigating daylight quality using self-shading strategy in energy commission building in Malaysia. Indoor and Built Environment, 22(5), 822-835.

Pacheco, R., Ordóñez, J., \& Martínez, G. (2012). Energy efficient design of building: A review. Renewable and Sustainable Energy Reviews, 16(6), 3559-3573. https://doi.org/10.1016/j.rser.2012.03.045.

Pathirana, S., Rodrigo, A., \& Halwatura, R. (2019). Effect of building shape, orientation, window to wall ratios and zones on energy efficiency and thermal comfort of naturally ventilated houses in tropical climate. International Journal of Energy and Environmental Engineering, 10(1), 107-120.

Patil, K., Kaushik, S., \& Aggarwal, A. (2020). Evaluation of Natural Ventilation Potential for Indoor Thermal Comfort in a Low-Rise Building in Arid and Semi-arid Climates of India. In Zhang G., Kaushika N., Kaushik S., \& Tomar R. (Eds.), Advances in Energy and Built Environment (Vol. 36, pp. 203-221). Singapore: Springer. https://doi.org/10.1007/978-981-13-7557$6 \_18$.

Qahtan, A. M. (2019). Thermal performance of a double-skin façade exposed to direct solar radiation in the tropical climate of Malaysia: A case study. Case Studies in Thermal Engineering, 14, 100419.

Ricciu, R., Galatioto, A., Desogus, G., \& Besalduch, L. (2018). Uncertainty in the evaluation of the Predicted Mean Vote index using Monte Carlo analysis. Journal of environmental management, 223, $16-22$. https://doi.org/10.1016/j.jenvman.2018.06.005.

Rodrigues, E., Fernandes, M. S., Gaspar, A. R., Gomes, Á., \& Costa, J. J. (2019). Thermal transmittance effect on energy consumption of Mediterranean buildings with different thermal mass. Applied Energy, 252, 113437.

Sanaieian, H., Tenpierik, M., van den Linden, K., Seraj, F. M., \& Shemrani, S. M. M. (2014). Review of the impact of urban block form on thermal performance, solar access and ventilation. Renewable and Sustainable Energy Reviews, 38, 551-560. https://doi.org/10.1016/j.rser.2014.06.007.

Schiefelbein, J., Rudnick, J., Scholl, A., Remmen, P., Fuchs, M., \& Müller, D. (2019). Automated urban energy system modeling and thermal building simulation based on OpenStreetMap data sets. Building and environment, 149, 630-639.

SEDA. (2019). Overview of Sustainable Energy Development Authority (SEDA). Putrajaya: SEDA. Retrieved on May 18, 2019, from www.seda.gov.my.

Shaikh, P. H., Nor, N. B. M., Sahito, A. A., Nallagownden, P., Elamvazuthi, I., \& Shaikh, M. (2017). Building energy for sustainable development in Malaysia: A review. Renewable and Sustainable Energy Reviews, 75, 1392-1403. 
Sharif, S. A., \& Hammad, A. (2019). Simulation-based multi-objective optimization of institutional building renovation considering energy consumption, life-cycle cost and life-cycle assessment. Journal of Building Engineering, 21, 429-445. https://doi.org/10.1016/j.jobe.2018.11.006.

Soonmin, H., Abraham, L., Okoroigwe, E. C., \& Urrego, L. R. (2019). Investigation of Solar Energy: The Case Study in Malaysia, Indonesia, Colombia and Nigeria. International Journal of Renewable Energy Research (IJRER), 9(1), 86-95.

Sorrell, S. (2015). Reducing energy demand: A review of issues, challenges and approaches. Renewable and Sustainable Energy Reviews, 47, 74-82. https://doi.org/10.1016/j.rser.2015.03.002.

St. Clair, P., \& Hyde, R. (2009). Towards a new model for climate responsive design at the university of the sunshine coast chancellery. Journal of green building, 4(3), 3-20.

Sulaiman, S. A. (2019). Strategy for Cooling of Computing Data Center Facilities. In Sulaiman S. (Ed.), Sustainable Thermal Power Resources Through Future Engineering (p. 73-84). Singapore: Springer. https://doi.org/10.1007/978-981-132968-5_6.

Susan, M. Y., \& Prihatmanti, R. (2017). Daylight characterisation of classrooms in heritage school buildings. Planning Malaysia: Journal of The Malaysian Institute of Planners, 15, 209.

Susca, T. (2019). Green roofs to reduce building energy use? A review on key structural factors of green roofs and their effects on urban climate. Building and environment, 162, 106273. https://doi.org/10.1016/j.buildenv.2019.106273.

Toparlar, Y., Blocken, B., Maiheu, B., \& Van Heijst, G. (2017). A review on the CFD analysis of urban microclimate. Renewable and Sustainable Energy Reviews, 80, 1613-1640.

United Nations. (2018). 68\% of the world population projected to live in urban areas by 2050, says UN. Department of Economic and Social Affairs, United Nations: New York. Retrieved on July 15, 2019, from https://www.un.org/development/desa/en/news/population/2018-revision-of-world-urbanization-prospects.html

Wang, W., Rivard, H., \& Zmeureanu, R. (2006). Floor shape optimization for green building design. Advanced Engineering Informatics, 20(4), 363-378.

Zhang, J., Xu, L., Shabunko, V., Tay, S. E. R., Sun, H., Lau, S. S. Y., \& Reindl, T. (2019). Impact of urban block typology on building solar potential and energy use efficiency in tropical high-density city. Applied Energy, 240, 513-533. https://doi.org/10.1016/j.apenergy.2019.02.033.

Editor: Fábio Duarte

Received: 28 Jul. 2020

Approved: 01 nov. 2020 